\title{
Evaluation of a New Adhesive Liner as an Adhesive Promotor and a Desensitizer on Hypersensitive Dentin
}

\author{
Junji TAGAMI*, Hiroyasu HOSODA*, Yoji IMAI** and Eiichi MASUHARA*** \\ *Department of Operative Dentistry, Faculty of Dentistry, Tokyo Medical and Dental University, 1-5- \\ 45, Yushima, Bunkyo-ku Tokyo 113, Japan \\ **Division of Functional Polymers, Institute for Medical and Dental Engineering, Tokyo Medical and \\ Dental University, 2-3-10, Kanda-Surugadai, Chiyoda-ku, Tokyo 101, Japan \\ ***Japan Institute of Advanced Dentistry, 2-1-47, Kanda-Surugadai, Chiyoda-ku, Tokyo 101 Japan
}

Received on July 31,1987

Accepted on September 30, 1987

The effect of N-methacryloyl aminosalicylic acid (NMSA) on the tensile bond strength between resin materials and bovine dentin and also its desensitizing efficacy on hypersensitive dentin were investigated.

In case of a composite resin, significantly greater bond was obtained by a combined treatment with $10 \%$ citric acid containing $3 \% \mathrm{CuCl}_{2}(10-3$ solution) and NMSA-liner, than that of the control group treated by $\mathrm{H}_{3} \mathrm{PO}_{4}$ only. Bond strength of MMA/TBB system resin was also promoted by NMSA application. In the clinical evaluation, the application of NMSA-liner has relieved most cases of the dentin hypersensitivity immediately after even a simple coating. For obtaining the long term effect, the dentin surface should be treated at first by 10-3 solution, though the efficacy was eliminated after a few days in some cases. Accordingly, this material seems to be promising both in the field of conservative dentistry and adhesive dentistry.

Key words : NMSA, Adhesion promotor, Desensitizer

\section{INTRODUCTION}

The development in a adhesive dentistry has rapidly grown in the past few years by the improvements of adhesive resin materials which bond strongly, particularly to dentin ${ }^{1-3)}$. It is generally considered, however, that the composite resin restorations with the acid-etch procedure irritate the dental pulp ${ }^{4,5}$. On the other hand, some researchers have proved that a good bond and adaptation between the resin restoration and dentinal walls did not cause significant pulpal responses ${ }^{6-8}$. However, we, in the routine clinic situation, are still bothered by postoperative sensitivity. Recently, a bonding liner containing an aromatic monocarboxylic acid derivative, which was expected to promote the adhesion between a resin material and enamel, has been reported to be effective even for protection against dental pulp irritation ${ }^{9)}$.

From another approach we predicted a more probable desensitizing effect of a salicylic acid derivative on dentin. Fortunately, Kojima et al. ${ }^{10)}$ have reported the copolymerization of $\mathrm{N}$-methacryloyl aminobenzoic acids and aminosalicylic acids with MMA. Additionally, $2 \%$ MMA solution of these acids were prepared in adhesion between ivory and acrylic resisns, and $\mathrm{N}$-methacryloyl 5 -aminosalicylic acid produced the strongest adhesion, showing approximately $20 \mathrm{MPa}$. The purpose of this study was to evaluate the effects of this material when modified as an adhesive liner, not only as an adhesion promotor, but also as a desensitizer on hypersensitive dentin. 


\section{MATERIALS AND METHODS}

\section{Tensile adhesion test}

Bovine teeth, kept in a refrigerater, were used. For the adherend, flat dentin surfaces were prepared by grinding buccal enamel and polishing it with a $\# 600$ waterproof silicon carbide paper.

The dintin surfaces were conditioned for 1 minute each with the following acidic solutions : $37 \%$ phosphoric acid $\left(\mathrm{H}_{3} \mathrm{PO}_{4}\right)$ and $10 \%$ citric acid containing $3 \%$ cupric chloride (10-3 solution).

After washing and drying the dentin surfaces, $5 \%$ NMSA (N-methacryloyl 5aminosalicylic acid, Fig. 1) in acetone solution (NMSA-liner) was used as an adhesive liner. NMSA was prepared by the reaction of methacrylic chloride with 5 -aminosalicylic acid. 4META (4-methacryloxyethyl trimellitic anhydride) was also made by the condensation of 2-hydroxyethyl methacrylate and trimellitic anhydride acid chloride, with pyridine as the hydrochloric acid acceptor. Five percent 4META in acetone solution (4META-liner) was employed as a control liner.<smiles>C=C(C)C(=O)Nc1ccc(O)c(C(=O)O)c1</smiles>

Fig. 1 N-methacryloyl 5-aminosalicylic acid.

An attached bonding agent of a composite resin* was thinly coated on the lined dentin, before the composite resin was inserted in the copper tube placed on the dentin surface. The testing method was the same as that described previously ${ }^{11}$.

In addition, the bond strength of the mixture of PMMA (polymethylmethacrylate) and MMA (methylmethacrylate) activated by TBB (tributylborane) to dentin was also examined, by carefully placing an acrylic rod on the lined dentin surfaces according to the method described before ${ }^{2)}$. MMA containing 2\% NMSA was also tested without liner. As a control, Super Bond $C \& B^{* *}$ was used without liner because this product is composed of PMMA and MMA containing $5 \%$ 4META activated by TBB.

Ten minutes after mixing the materials, the bonded specimens were immersed in water at $37^{\circ} \mathrm{C}$ and stored for 1 day before the tensile bond strength was determined by the Instrontype universal testing machine ${ }^{* * *}$.

Ten specimens were used in each group.

2. Analysis of the desensitizing effect of NMSA on hypersensitive dentin

The desensitizing effect of NMSA-liner on hypersensitive dentin was clinically evaluated. This evaluation was conducted on the teeth of 76 healthy people, who had suffered from dentinal hypersensitivity accompanied by gingival recession or/and abrasion.

At first, the hypersensitive area was carefully tested by cold air stimulus, using an air gun

\footnotetext{
* Clearfil FII New Bond, Kuraray Co., Osaka, Japan

** Sun Medical Co., Tokyo, Japan

*** Shimadzu Autograph AG-500B, Shimadzu Co., Kyoto, Japan
} 
attached to the dental chair and given a score as the baseline. The treatment with 10-3 solution was performed for 30 seconds to clean the surface of hypersensitive area. After washing and drying, NMSA-liner was applied with a sponge pellet. After the evaporation of acetone, the same hypersensitive area was retested by cold air for assessing the effect immediately after application. One week after the application, the treated area was checked again in the same way.

The NMSA-liner application without 10-3 treatment was also evaluated.

Rating scales for the responses to the stimulus were ranked as follows : 0 , no pain ; 1 , awareness of stimulus or discomfort; 2, pain, but not severe; 3 , severe pain. By the comparison of the rank between evaluations at the baseline and each period after the liner application, the desensitizing efficacy of the NMSA-liner was judged as follows : remarkable effect, which indicates decrease in score from 3 to 1 or 0 and from 2 to 0 ; moderate effect, which indicates decrease in score from 3 to 2 , from 2 to 1 and from 1 to 0 ; none effect, which indicates no change at all.

3. SEM investigation

The dentin of the extracted human incisor, ground and polished with a $\# 600$ water-proof silicon carbide paper and treated variously with $10-3$ solution and liners, was investigated by a SEM****.

\section{RESULTS}

\section{Adhesion}

Table 1 shows the tensile adhesion of the composite resin to bovine teeth after various treatments. These results were discussed with analysis of variance followed by Newman Keul's tests. The strongest bond was obtained from the treatments with 10-3 solution and 4META-liner. The control group treated by $\mathrm{H}_{3} \mathrm{PO}_{4}$ without any liner produced the weakest bond of $3.4 \mathrm{MPa}$, showing significant differences from those of the groups treated with 4META-liner or NMSA-liner.

Table 1 Tensile bond strengths of a composite resin bonded to treated bovine dentin

\begin{tabular}{ccc}
\hline Surface treatment & Liner & Adhesion (S. D.) MPa \\
\hline $10-3$ & 4META-liner & $9.9(3.4)$ \\
$10-3$ & NMSA-liner & $6.9(1.7)$ \\
$\mathrm{H}_{3} \mathrm{PO}_{4}$ & 4META-liner & $8.5(1.8)$ \\
$\mathrm{H}_{3} \mathrm{PO}_{4}$ & NMSA-liner & $5.9(2.0)$ \\
$\mathrm{H}_{3} \mathrm{PO}_{4}$ & - & $3.4(1.3)$
\end{tabular}

Vertical bars on the right indicate that the figures at both ends are significantly different $(p<0.05)$.

When the PMMA/MMA-TBB system resin was used, the bond strength was much stronger than that of the composite resin (Table 2). The groups treated with $\mathrm{H}_{3} \mathrm{PO}_{4}$ solution showed significantly smaller bond strength than that of the groups treated with 10-3 solution. Combined treatment with 10-3 solution and NMSA-liner produced very strong bonds, similar 
Table 2 Tensile bond strengths of PMMA/MMA-TBB resin bonded to treated dentin

\begin{tabular}{cclr}
\hline Treatment & Liner & \multicolumn{1}{c}{ MMA Monomer } & Adhesion (S. D.) MPa \\
\hline $10-3$ & NMSA-liner & MMA & $17.3(4.5)$ \\
$10-3$ & - & $2 \%$ NMSA/MMA & $18.1(2.7)$ \\
$10-3$ & - & $5 \%$ 4META/MMA & $17.2(3.7)$ \\
$\mathrm{H}_{3} \mathrm{PO}_{4}$ & NMSA-liner & MMA & $7.9(1.9)$ \\
$\mathrm{H}_{3} \mathrm{PO}_{4}$ & - & $2 \%$ NMSA/MMA & $13.5(4.1)$ \\
$\mathrm{H}_{3} \mathrm{PO}_{4}$ & - & $5 \%$ 4META/MMA & $10.6(2.4)$ \\
\hline
\end{tabular}

Vertical bars on the right indicate that the figures at both ends are significantly different $(\mathrm{p}<0.05)$.

to that of Super Bond C\&B. When MMA containing $2 \%$ NMSA was used, a strong bond was also obtained, the same as with Super Bond C\&B.

2. Desensitizing effect

Table 3 shows the results of the clinical evaluations. When NMSA-liner was applied after 10-3 treatment, $99 \%$ rated effective immediately after application. That is, $87 \%$ of the teeth showed remarkable effect, $12 \%$ were moderate, and only 1 case showed no effect. But 1 week after the application, $29 \%$ had no effect. A significant difference was found between the immediate postapplication evaluation and the evaluation after 1 week, according to a rank sum test (Wilcoxon's test). When the liner was applied without $10-3$ treatment, $83 \%$ of the teeth was rated effective at the immediate postapplication evaluation. But after 1 week, $55 \%$ were not effected.

Table 3 Results of clinical evaluation

\begin{tabular}{rlrrr}
\hline $10-3$ & Evaluation Period & remarkable & moderate & none \\
\hline \multirow{2}{*}{ treated } & immediate & $94(87 \%)$ & $13(12 \%)$ & $1(1 \%)$ \\
untreated & I week & $68(63 \%)$ & $9(8 \%)$ & $31(29 \%)$ \\
& immediate & $22(55 \%)$ & $11(28 \%)$ & $7(18 \%)$ \\
& 1 week & $7(18 \%)$ & $11(28 \%)$ & $22(55 \%)$ \\
\hline
\end{tabular}

Significant differences $(\mathrm{p}<0.01)$ were found among the all groups.

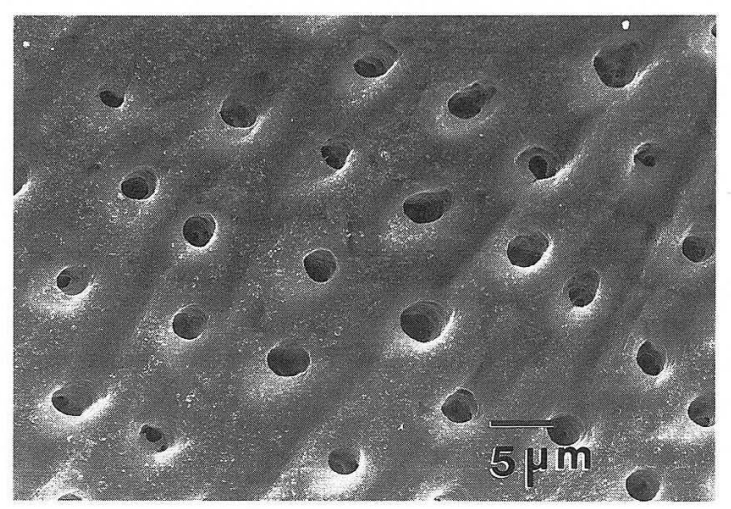

Fig. 2 Dentinal surface ground and treated with 10-3 solution. Dentinal tubules are opened with the 10-3 treatment. 


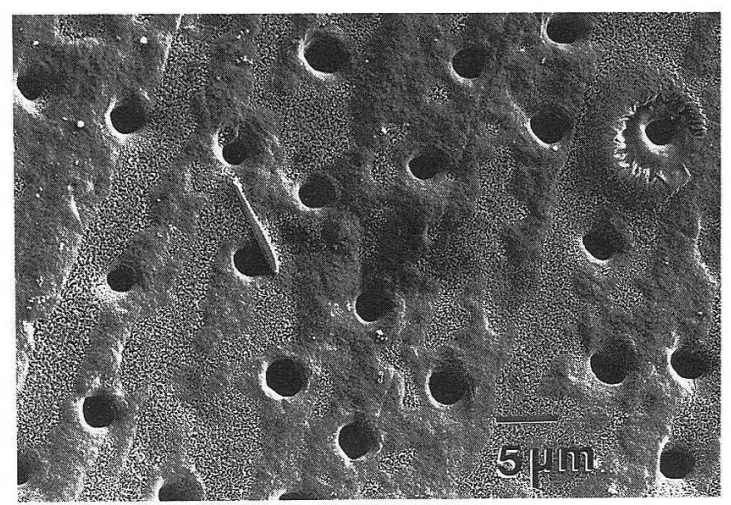

Fig. 3 Dentinal surface applied NMSA-liner after grinding and 10-3 treatment. Dentinal tubules are still opened.

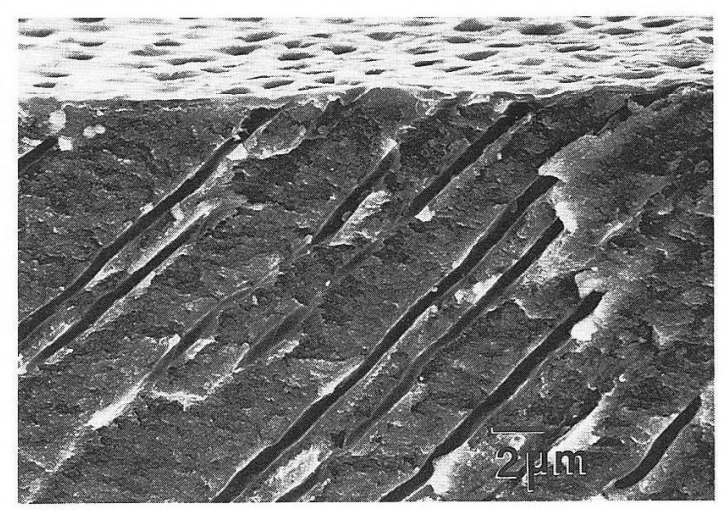

Fig. 4 Profile view of the specimen in Fig. 3. Dentinal tubules are not occluded even at the deep area.

When comparing 10-3 treated group with the untreated group, the significant differences were found in both evaluations immediately after application and 1 week after application. 3. SEM investigation

Figure 2 shows the dentin treated with 10-3 solution, indicating the tubules opened when the smear layer and the dentinal plug dissolved. The tubules were still open in spite of the application of NMSA-liner (Fig. 3). Even in the observation of the divided specimen, the occlusion at the deep area of the tubules could not be confirmed (Fig. 4).

\section{DISCUSSION}

In this study, the application of NMSA-liner increased the bond strength of a composite resin or MMA/TBB resin to bovine dentin. In the case of the composite resin, 4META-liner produced a stronger bond than NMSA-liner. The bond strength of the mixture of PMMA and MMA containing $2 \%$ NMSA was similar to that of Super Bond C\&B. 
Bowen $e t a l .{ }^{1)}$ reported that applications of a cleanser/mordant solution, a surface active comonomer, and a coupling agent, produced a strong bond of composite resin to dentin. Though a mild acidic solution is recommended to remove the smear layer ${ }^{12)}$, dentin etching with $\mathrm{H}_{3} \mathrm{PO}_{4}$ solution has been performed to obtain a stronger bond of composite, in Japan ${ }^{11,13}$. In this study, however, the treatment with $\mathrm{H}_{3} \mathrm{PO}_{4}$ was comfirmed not to be suitable for bonding of MMA/TBB resin to dentin. The result coincides with a previous study by Nakabayashi et $a l_{.}{ }^{2}$. The treatment with 10-3 solution is considered best to prepare a suitable condition for 4META or NMSA to be used on dentin.

Unfortunately, the etiology of the dentinal hypersensitivity has so far been unclear because the mechanism of pain transmission within the dentin is still doubtful. Although several theories have been suggested for hypersensitive dentin, it appears the hydrodynamic theory is most plausible. And the applications of medicaments aiming at the occluding of the dentinal tubules have generally been used in the clinic on a trial and error basis. However, Mosteller ${ }^{14)}$ reported that predonisolone eliminated the postoperative thermal sensitivity of dentin. The authors anticipate some anodyne effect of NMSA, because it is an aminosalicylic acid derivative. In preliminary investigation, the dose-toxic effect of this material was confirmed to be similar to that of para-aminosalicylic acid (PAS) which is an antituberculosis drug, though the pharmacological effect of NMSA has not been investigated yet. Actually, the desensitizing effect was observed in a clinical trial, when used as the adhesive liner before the composite restoration. Thus, the preliminary clinical evaluation was performed.

On the other hand, it has been reported that the occlusion of the patent tubules established a protective diffusion barrier, and that the hydraulic conductance of dentin increased when etched with $\mathrm{acid}^{15}$. In this study, however, the application of NMSA-liner with 10-3 treatment was more effective when compared to the application without 10-3 treatment. The SEM investigation did not show the image of occlusion nor sealing of the opened tubules. Subsequently, it is considered that the patent tubules and the dentinal surfaces conditioned by 10-3 solution would promote the penetration of NMSA-liner. This also suggests that even in case of application of other desensitizing agents, the specific surface cleansing or treatment suitable for each medicament or agent may increase the effect.

The fact that almost all the cases showed some desensitizing effect immediately after the application of NMSA-liner with or without 10-3 treatment might also suggest that it allows for increased accomodation to sensitivity, as was seen by the repeated cold air stimulus during the procedure and the cooling of the tooth by the evaporation of acetone. Even if NMSA has an anodyne effect, the effect seems not to continue very long. The temporary changes of threshold pain might change the sensitivity of the tooth.

Though further investigation needs to be done, the application of this liner is considered to be very useful in the clinic, since it is effective not only for the hypersensitivity, but also for the bonding of composite resin. Furthermore, it may be able to decrease the postoperative sensitivity, contribute to good restoration for the root surface caries, and bring about great benefits in geriatric dentistry. 


\section{CONCLUSION}

1. NMSA-liner produced a strong bond of composite resin or MMA/TBB resins to bovine dentin.

2. The use of 10-3 solution may provide a compatible condition for NMSA-liner to be used on dentin.

3. NMSA-liner was effective in desensitizing hypersensitive dentin, especially immediately after the application, but the effect diminished after 1 week in some cases.

\section{ACKNOWLEDGEMENT}

The authors wish to thank Dr. Yoshinori Kadoma and Mr. Katsunori Kojima, Division of Functional Polymers, Institute for Medical and Dental Engineering, Tokyo Medical and Dental University, for supplying NMSA and 4META and valuable suggestions, and to Dr. Akitomi Nakajima for assistance.

\section{REFERENCES}

1) Bowen, R. L., Cobb, E. N. and Rapson, J. E. : Adhesive bonding of various materials to hard tooth tissues: Improvement in bond strength to dentin, J Dent Res 61: 1070-1076, 1982.

2) Nakabayashi, N., Takeyama, M., Kojima, K. and Masuhara, E. : Studies on dental self -curing resins (19) Adhesion of 4-META/MMA-TBB resin to pretreated dentin, J Japan Soc Dent Appar Mat 23: 29 $-33,1982$. (in Japanese)

3) Munksgaard, E. C., Itoh, K., Asmussen, E. and J $\phi$ rgensen, K. D. : Effect of combining dentin bonding agents, Scand J Dent Res 93: 377-380, 1985.

4) Macko, D. J., Rutberg, M. and Langeland, K. : Pulpal response to the application of phosphoric acid to dentin, Oral Surg 45: 930-946, 1978.

5) Vojinovic, O., Nyborg, H. and Brännström, M. Acid treatment of cavities under resin fillings : Bacterial growth in dentinal tubules and pulpal reactions, J Dent Res 52: 1189-1193, 1973.

6) Kanehira, M. : Adaptation and pulp response of composite resin, Japan J Conserv Dent 27: 516-533, 1984. (in Japanese)

7) Inokoshi, S., Iwaku, M. and Fusayama, T.: Pulpal response to a new adhesive restorative resin, $J$ Dent Res 61: 1014-1019, 1982.

8) Fujitani, M. : Effects of acid-etching, marginal microleakage and adaptation to dentinal wall on the dental pulp in adhesive composite restorations, Japan J Conserv Dent 29: 228-253, 1986. (in Japanese)

9) Nakamura, T. and Goto, G.: Clinical evaluation of the effects of a bonding liner containing an aromatic monocarboxylic acid derivative on primary teeth, Shikuwa Gakuho 85: 1439-1443, 1985. (in Japanese)

10) Kojima, K., Iwabuchi, S., Kunagi, M., Kikuchi, J. and Iida, K. : Studies of the polymer ligands (3) : Preparations and copolymerizations of $\mathrm{N}$-methacryloyl aminobenzoic acids and aminosalicylic acids, Journal of Faculty of Engineering Chiba University 25 (48): 65-72, 1974. (in Japanese)

11) Fusayama, T., Nakamura, M., Kurosaki, N. and Iwaku, M.: Non-pressure adhesion of a new adhesive restorative resin, J Dent Res 58: 1364-1370, 1979.

12) Brännström, M., Nordenvall, K. J. and Glantz, P-O.: The effect of EDTA-containing surface active solutions on the morphology of prepared dentin, J Dent Res 59: 1127-1131, 1980.

13) Nakajima, A., Tagami, J. and Hosoda, H. : Bond strength of adhesive composite resins. Part 3. Effect of acid etching techniques on dentin adhesion, Japan J Conserv Dent 29: 1267-1279, 1986. (in Japanese)

14) Mosteller, J.H.: Use of predonisolon in the elimination of post operative thermal sensitivity. A clinical study, J Prosthet Dent 12: 1176-1179, 1962. 
15) Pashley, D. H., Michelich, V. and Kehl, T.: Dentin permeability : effects of smear layer removal, $J$ Prosthet Dent 46 : 531-537, 1981. 
また軟組織との反応において中実体では $\mathrm{Zr}$ - Ti 合金 はアパタイトやチタンとはあまり差異がみられなかっ
た。多孔材では上皮が多孔材部を完全におおうように治 瘺した場合に結合組織が入り強固な結合が得られた。

新しい接着性ライナーの接着促進効果と象牙質知覚過敏鈍麻作用の評価

田上順一*, 細田裕康 ${ }^{*}$, 今井庸二**, 増原英一***

*東京医科歯科大学歯学部第一歯科保存学教室

**東京医科歯科大学医用器村研究所機能性高分子部門 ***総合歯科医療研究所

サリチル酸の誘導体であるN-メタクリロイルアミ，

サリチル酸 (NMSA) に着目し, その接着性ライナーと

しての評価のみならず象牙質に対する知覚鈍麻作用につ

いても検討した。

その結果， $5 \%$ NMSA アセトン溶液を調整し NMSA ライナーとして用いると, 牛象牙質に対する各種レジン 材料の引つ張り接着強さが向上することが確認された。
また象牙質知賞過敏症に対する本剤の塗布効果を臨床的 に評価したところ，染布直後においては，ほとんどすべ ての症例において症状の消退がみられ，臨床的に極めて 効果的であることが示唆された。数日後にその効果の消 退する例もみられたが, 塗布面に対する $10-3$ 溶液によ る前処理の有効性も確認された。本剤の象牙質知覚過敏 症に対する作用機序については現在検討中である。 